\title{
MEDIA BELAJAR INTERAKTIF DALAM PEMBELAJARAN BERBASIS CONTEXTUAL TEACHING AND LEARNING PADA BIDANG STUDI EKONOMI
}

\author{
Marizal Sirumapea ${ }^{1}$, Abdul Muin Sibuea ${ }^{2}$, R. Mursid $^{3}$ \\ ${ }^{1}$ SMA Negeri 20 Medan, Sumatera Utara \\ ${ }^{2,3}$ FT Universitas Negeri Medan, Sumatera Utara \\ marizalsirumapea@gmail.com
}

\begin{abstract}
Abstrak: Penelitian bertujuan untuk mengembangkan media pembelajaran Contextual Teaching And Learning. Media pembelajaran interaktif berbasis CTL ini tentang materi Pembangunan Ekonomi dan Pertumbuhan Ekonomi dengan subjek penelitian pada SMA Negeri 20 Medan. Tahap perancangan media berupa naskah media yang akan dikembangakan. Tahap pengembangan dilakukannya penilaian pada hasil media kemudian diuji cobakan terhadap siswa skala kecil dan skala besar. Berdasarkan hasil penelitian pengembangan media pembelajaran media interaktif berbasis CTL sangat layak digunakan dalam pembelajaran. Terbukti dengan penilaian oleh ahli materi mendapat nilai rata-rata 3,69 dengan tingkat kelayakan 74,00\% dengan kategori "Layak", ahli media mendapat nilai rata-rata 4,36 dengan tingkat kelayakan 89\% dengan kategori "Sangat Layak", ahli desain pembelajaran 4,00 dengan tingkat kelayakan 80\% dengan kategori "Layak" dan guru ekonomi 3,87 dengan tingkat kelayakan 77,34\% dengan kategori "Sangat Layak" serta pendapat siswa pada uji skala kecil 4,26 dengan tingkat kelayakan $85 \%$ dengan kategori "Sangat Layak" selanjutnya uji skala besar 4,30 dengan tingkat persentase kelayakan 86 $\%$ dengan kategori "Sangat Layak".
\end{abstract}

Kata Kunci : media belajar interaktif, contextual teaching and learning, ekonomi.

\begin{abstract}
Research aims to develop Contextual Teaching And Learning learning media. CTL-based interactive learning media is about the material of Economic Development and Economic Growth with research subjects at Medan State High School 20. The media design stage is in the form of a media script that will be developed. The stage of developing assessment on media results was then tested on small and large scale students. Based on the results of research on the development of CTL-based interactive media learning media it is very feasible to use in learning. Evidenced by the assessment by material experts got an average score of 3.69 with a feasibility level of $74.00 \%$ with the category "Eligible", media experts got an average score of 4.36 with an eligibility rate of $89 \%$ with the category "Very Worthy", experts 4.00 learning design with $80 \%$ feasibility level with "Eligible" category and economic teacher 3.87 with a feasibility level of $77.34 \%$ with "Very Eligible" category and student opinion on small scale test 4.26 with $85 \%$ feasibility level with the "Very Worthy" category then tested a large scale of 4.30 with a percentage level of $86 \%$ eligibility in the "Very Worthy" category.
\end{abstract}

Keywords: interactive learning media, contextual teaching and learning, economics.

\section{PENDAHULUAN}

Untuk mencerdaskan kehidupan bangsa merupakan tujuan dan cita-cita setiap bangsa di dunia. Salah satu faktor pendukung utama bagi kemajuan suatu negara adalah pendidikan. Betapa pentingnya pendidikan sehingga dijadikan sebagai tolak ukur kemajuan suatu bangsa.

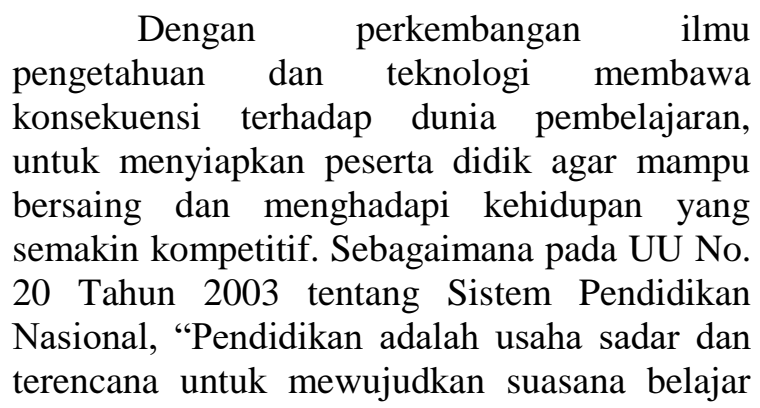


dan proses pembelajaran agar peserta didik secara aktif mengembangkan potensi dirinya untuk memiliki kekuatan spiritual keagamaan, pengendalian diri, kepribadian, kecerdasan, akhlak mulia serta ketrampilan yang diperlukan dirinya, masyarakat, bangsa dan negara."

Dengan menggunakan media belajar dapat membantu proses belajar siswa dalam poses belajar mengajar yang pada gilirannya dapat mempertinggi hasil belajar yang ingin dicapai. Dampak positif dari penggunaan media sebagai bagian integral pembelajaran dikelas atau sebagai cara utama pembelajaran langsung menurut Arsyad (2013:25-27) adalah: (1) penyampaian pelajaran menjadi lebih baku; (2) pembelajaran bisa lebih menarik; (3) pembelajaran menjadi lebih interaktif dengan diterapkannya teori belajar dan prinsip-prinsip psikologis yang diterima dalam hal partisipasi siswa, umpan balik, dan penguatan; (4) lama waktu pemebelajaran yang diperlukan dapat dipersingkat; (5) kualitas hasil belajar dapat ditingkatkan; (6) pembelajaran dapat diberikan kapan dan dimana diinginkan atau diperlukan; (7) sikap positif siswa terhadap apa yang mereka pelajari dan terhadap proses belajar dapat ditingkatkan; (8) peran guru dapat berubah ke arah yang lebih positif.

Menurut Dale dalam Arsyad (2013:27) manfaat media belajar adalah: (1) meningkatkan rasa saling pengertian dan simpati dalam kelas; (2) membuahkan perubahan signifikan tingkah laku siswa; (3) menunjukkan hubungan antara mata pelajaran dan kebutuhan dan minat siswa dengan meningkatnya motivasi belajar siswa; (4) membawa kesegaran dan variasi bagi pengalaman belajar siswa; (5) membuat hasil belajar lebih bermakna bagi berbagai kemampuan siswa; (6) mendorong pemanfaatan yang bermakna dari mata pelajaran dengan jalan melibatkan imajinasi dan partisipasi aktif yang mengakibatkan meningkatnya hasil belajar; (7) memberikan umpan balik yang diperlukan yang dapat membantu siswa menemukan seberapa banyak telah mereka pelajari; (8) melengkapi pengalaman yang kaya dengan pengalaman itu konsep-konsep yang bermakna dapat dikembangkan (9) memperluas wawasan dan pengalaman siswa yang mencerminkan pembelajaran nonverbalistik dan membuat generalisasi yang tepat; (10) meyakinkan diri bahwa urutan dan kejelasan pikiran yang siswa butuhkan jika mereka membangun struktur konsep dan sistem gagasan yang bermakna.

Encyclopedia of Educational Reserarch mencirikan manfaat media belajar sebagai berikut: (1) meletakkan dasar-dasar yang konkret untuk berfikir, oleh karena itu mengurangi verbalisme. (2) memperbesar perhatian siswa. (3) meletakkan dasar-dasar yang penting untuk perkembangan belajar, oleh karena itu membuat pelajaran lebih mantap. (4) memberikan pengalaman nyata yang dapat menumbuhkan kegiatan berusaha sendiri di kalangan siswa. (5) menumbuhkan pemikiran yang teratur dan kontinyu, terutama melalui gambar hidup. (6) membantu tumbuhnya pengertian yang dapat membantu perkembangan kemampuan berbahasa. (7) memberikan pengalaman yang tidak mudah diperoleh dengan cara lain, dan membantu efisiensi dan keragaman yang lebih banyak dalam belajar.

Dengan demikian, manfaat praktis dari penggunaan media belajar di dalam proses belajar mengajar menurut Azhar Arsyad (2013:29) antara lain:

1. Media belajar dapat memperjelas penyajian pesan dan informasi sehingga dapat memperlancar dan meningkatkan proses dan hasil belajar.

2. Media belajar dapat meningkatkan dan mengarahkan perhatian anak sehingga dapat menimbulkan motivasi belajar, interaksi yang lebih langsung antara siswa dan lingkungannya, dan kemungkinan siswa untuk belajar sendiri-sendiri sesuai dengan kemampuan dan minatnya.

3. Media belajar dapat mengatasi keterbatasan indera, ruang dan waktu;

a. Objek atau benda yang terlalu besar untuk ditampilkan langsung di ruang kelas dapat diganti dengan gambar, foto, slide, realita, film, atau model;

b. Objek atau benda yang terlalu yang terlalu kecil yang tidak tampak oleh indera dapat disajikan dengan bantuan mikroskop, film, slide, atau gambar;

c. Kejadian langka yang terjadi di masa lalu atau terjadi sekali dalam puluhan tahun dapat ditampilkan melalui rekaman video, film, foto, slide di samping secara verbal.

d. Objek atau proses yang amat rumit seperti peredaran darah dapat ditampilkan secara konkret melalui 
film, gambar slide, atau simulasi komputer;

e. Kejadian atau percobaan yang dapat membahayakan dapat disimulasikan dengan media seperti komputer, film, dan video.

f. Peristiwa alam seperti terjadinya letusan gunung berapi atau proses yang dalam kenyataan memakan waktu lama seperti proses kepompong menjadi kupu-kupu dapat disajikan dengan teknik-teknik rekaman seperti timelapse untuk film, video, slide, atau simulasi komputer.

4. Media belajar dapat memberikan kesamaan pengalaman kepada siswa tentang peristiwa-peristiwa di lingkungan mereka, serta memungkinkan terjadinya interaksi langsung dengan guru, masyarakat, dan lingkungannya misalnya melalui karyawisata, kunjungan-kunjungan ke museum atau kebun binatang.

Belajar dan pembelajaran adalah istilah yang saling terkait dan yang sangat erat dan tidak dapat dipisahkan satu dengan lain dalam proses pendidikan. Schunk (2012:6), dari sebuah perspektif filosofis, pembelajaran dapat didiskusikan di bawah judul epistemologi yang mengacu pada studi tentang asal mula, karakteristik, batasan-batasan, dan metodemetode pengetahuan. Bagaimana kita bisa tahu? Bagaimana kita bisa belajar sesuatu yang baru? Apa yang menjadi sumber dari pengetahuan?

Belajar dan pembelajaran merupakan suatu kegiatan yang bisa terjadi secara simultan. Pendapat tentang pengertian pembelajaran sebagaimana dialog antar pelajar terhadap guru yaitu Schunk (2012:1), pembelajaran adalah serangkaian kegiatan yang diusahakan dengan tujuan agar orang (misalnya guru, siswa) dapat melakukan aktifitas belajar. Pendapat tersebut dapat diartikan bahwa pembelajaran merupakan interaksi antara guru dan siswa dalam proses membantu peserta didik agar dapat belajar dengan baik.

Tujuan pembelajaran adalah suatu deskripsi tentang perubahan tingkah laku siswa setelah berlangsung pembelajaran. Menurut Dick \& Carey (2009), menjelaskan bahwa tujuan pembelajaran harus dapat diamati, seperti 'menyusun', 'menggunakan', atau 'mendemonstrasikan'. Bukan sekedar 'memahami', 'mengetahui', dan 'merasakan' yang tidak dapat diamati oleh mata. Jadi proses pembelajaran harus terkonsep dengan baik, guru harus mampu menyusun dan merumuskan tujuan pembelajaran secara jelas dan tegas.

Sedangkan menurut Roymond dan Simamora (2009:28), tujuan pembelajaran adalah perubahan tingkah laku yang positif dari peserta didik, seperti perubahan yang secara psikologis akan tampil dalam tingkah laku (overed behaviour), yang dapat diamati oleh alat indra oleh orang lain baik tutur kata, motorik, dan gaya hidup.

Kata ekonomi berasal dari sebuah kata dalam bahasa Yunani yaitu: "Oikos" dan "Nomos" hal ini merujuk pada pihak pengelolaan rumah tangga. Dengan kata lain, ilmu ekonomi merupakan cabang ilmu pengetahuan sosial yang berhubungan dengan kehidupan rumah tangga. Samuelson (dalam Sudarman 1999:11) bahwa ilmu ekonomi adalah, "Suatu studi mengenai bagaimana seharusnya manusia atau masyarakat menentukan pilihannya baik dengan atau tanpa menggunakan uang dalam memanfaatkan sumber daya yang terbatas jumlahnya dan yang mempunyai alternatif penggunaan untuk menghasilkan barang serta kemudian mendistribusikannya baik untuk keperluan sekarang atau masa yang akan datang diantara anggota-anggota masyarakat."

Dalam hal ini materi pembahasan tentang Pembangunan Ekonomi yaitu proses yang bertujuan menaikkan pendapatan per kapita untuk jangkah waktu yang panjang yang disertai dengan adanya perubahan struktur ekonomi dan perkembangan IPTEK. Pendapatan per kapita bisa naik bila persentase kenaikan PDB lebih besar dibanding persentase kenaikan jumlah penduduk.

Gagne \& Briggs (1979), Media Pembelajaran adalah berbagai komponen yang ada dalam lingkungan siswa dan dapat merangsang untuk belajar. Sedangkan menurut Sadiman (2014:6), media adalah perantara atau pengantar pesan dari pengirim ke penerima. Kata media berarti perantara: penghubung; yang terletak di antara dua pihak (orang, atau golongan). Kata "media" berasal dari bahasa latin dan merupakan bentuk jamak dari kata medium yang berarti perantara.

Seiring perkembangan teknologi, para pakar pendidikan mencari berbagai cara guna mengembangkan sebuah media pembelajaran agar memudahkan siswa dalam belajar. Dengan media pembelajaran akan terjadi komunikasi antara guru dengan siswanya, sehingga proses pembelajaran akan berjalan lancar dengan hasil 
yang maksimal. Gagne' dan Briggs (1975) dalam buku yang dikutip (Arsyad 2013:4), secara implisit mengatakan bahwa media pembelajaran meliputi alat yang secara fisik digunakan untuk menyampaikan isi materi pembelajaran, seperti buku, tape recorder, kaset, video camera, video recorder, film, slide (gambar bingkai), foto, gambar, grafik, televisi, dan komputer.

Menurut Bruner (dalam Arsyad 2013:13), hasil belajar seseorang dimulai dari pengalaman langsung (kongkrit), kenyataan yang ada di lingkungan kehidupan seseorang kemudian melalui benda tiruan, sampai kepada lambang verbal (abstrak). Semakin di puncak kerucut semakin abstrak media penyampaian pesan itu. Urutan ini tidak berarti proses belajar dan interaksi belajar mengajar harus selalu dimulai dari pengalaman langsung. Tetapi dimulai sesuai dengan kebutuhan dan kemampuan kelompok siswa yang dihadapi dengan pertimbangan situasi belajarnya.

Menurut Sanjaya (2006 : 170-171), media pembelajaran dapat diklasifikasikan menjadi beberapa klasifikasi tergantung dari sudut mana melihatnya. Dilihat dari sifatnya, media dapat dibagi ke dalam:

1. Media auditif, seperti: radio dan rekaman suara,

2. Media visual, seperti: film slide, foto transparansi, lukisan, gambar, dan media grafis lainnya,

3. Media audiovisual, seperti: rekaman video, berbagai ukuran film, slide suara, dan lain sebagainya.

Sedangkan menurut Arsyad (2013:31), berdasarkan perkembangan teknologi media pembelajaran dapat digolongkan menjadi 4 (empat) yaitu:

1. Media hasil teknologi cetak,

2. Media hasil teknologi audio-visual,

3. Media hasil teknologi yang berdasarkan komputer, dan

4. Media hasil gabungan teknologi cetak dan komputer.

Secara umum media pembelajaran merupakan alat bantu yang digunakan oleh orang (dalam hal ini adalah guru) untuk menyampaikan pesan kepada siswa. Sadiman (2014:17) berpendapat bahwa, secara umum media pembelajaran mempunyai fungsi memperjelas penyajian pesan agar tidak terlalu bersifat verbal, mengatasi keterbatasan ruang, waktu dan daya indera. Penggunaan media pembelajaran secara tepat dan bervariasi dapat mengatasi sikap pasif siswa. Dengan sifat yang unik pada setiap siswa ditambah dengan lingkungan dan pengalaman yang berbeda, sedang kurikulum dan materi pendidikan ditentukan sama untuk setiap siswa, maka guru banyak mengalami kesulitan bilamana semua harus diatasi sendiri. Hal ini akan lebih sulit bila latar belakang lingkungan guru dengan siswa berbeda. Masalah ini dapat diatasi dengan media pembelajaran, yaitu dengan kemampuannya dalam memberikan perangsangan yang sama, menimbulkan persepsi yang sama.

Menurut Levie \& Lentz (1982) yang dikutip (Arsyad 2013:20), mengemukakan empat fungsi media pembelajaran, khususnya visual, yaitu: (a) fungsi atensi, (b) fungsi afektif, (c) fungsi kognitif, dan (d) fungsi kompensatoris.

Menurut Daryanto (2010:5), mengungkapkan fungsi media pembelajaran:

1. Memperjelas pesan agar tidak terlalu verbalistis,

2. Mengatasi keterbatasan ruang, waktu tenaga dan daya indra,

3. Menimbulkan gairah belajar, interaksi lebih langsung antara siswa dengan sumber belajar,

4. Memungkinkan anak belajar mandiri sesuai dengan bakat dan kemampuan visual, auditori dan kinestetiknya,

5. Memberi rangsangan yang sama, mempersamakan pengalaman dan menimbulkan persepsi yang sama.

$$
\text { Sedangkan Arsyad (2013:25), }
$$

mengemukakan dampak positif dari penggunaan media pembelajaran yaitu:

1. Penyampaian pelajaran menjadi lebih baku,

2. Pembelajaran bisa lebih menarik,

3. Pembelajaran bisa lebih interaktif,

4. Lama waktu pembelajaran yang diperlukan dapat dipersingkat,

5. Kualitas hasil belajar dapat ditingkatkan bilamana integrasi kata dan gambar sebagai media pembelajaran dapat mengkomunikasikan konsep-konsep pengetahuan dengan terorganisir dengan baik, spesifik, dan jelas,

6. Pembelajaran dapat diberikan kapan dan dimana diinginkan atau diperlukan,

7. Sikap positif siswa terhadap apa yang mereka pelajari, dan terhadap proses belajar dapat ditingkatkan,

8. Peran guru dapat berubah kearah yang lebih positif, yaitu beban guru untuk penjelasan 
yang berulang-ulang mengenai isi pelajaran dapat dikurangi bahkan dihilangkan sehingga ia dapat memusatkan perhatian kepada aspek penting lain dalam proses belajar mengajar, misalnya sebagai konsultan atau penasehat siswa.

Menurut Arsyad (2013:74-76), mengemukakan beberapa kriteria yang patut diperhatikan dalam pemilihan media, yaitu:

1. Sesuai dengan tujuan yang ingin dicapai,

2. Tepat untuk mendukung isi pelajaran yang sifatnya fakta, konsep, prinsip, atau generalisasi,

3. Praktis, luwes, dan bertahan,

4. Guru terampil menggunakannya,

5. Pengelompokan sasaran,

6. Mutu teknis.

Sedangkan Sudjana dan Rivai (2002:4-

5), mengungkapkan kriteria-kriteria dalam memilih dan menggunakan media pembelajaran yaitu:

1. Ketepatannya dengan tujuan pembelajaran,

2. Dukungan terhadap isi bahan pembelajaran,

3. Kemudahan memperoleh media,

4. Keterampilan guru dalam menggunakannya,

5. Tersedia waktu untuk menggunakannya,

6. Sesuai dengan taraf berpikir peserta didik.

Berkembangnya komunikasi elektronik, membawa perubahan-perubahan besar dalam dunia pendidikan. Komputer sebagai media pembelajaran dikenal dengan nama pembelajaran dengan bantuan komputer atau Computer-Asssisted Instruction (CAI). Sedangkan komputer sendiri menurut Arsyad (2013:54), adalah mesin yang dirancang khusus untuk memanipulasi informasi yang diberi kode, mesin elektronik yang otomatis melakukan pekerjaan dan perhitungan sederhana dan rumit. Penyajian pesan dan informasi dalam CAI dapat berbentuk:

1. Tutorial,

2. Permainan instruksional,

3. Drill and practice, dan

4. Simulasi.

Keuntungan dengan pemanfaatan komputer sebagai media pembelajaran menurut Arsyad (2013:55), adalah:

1. Komputer dapat mengakomodasikan siswa yang lamban menerima pelajaran,

2. Komputer dapat merangsang siswa untuk mengerjakan latihan, kegiatan laboratorium atau simulasi,
3. Kendali berada ditangan siswa sehingga tingkat kecepatan belajar siswa dapat disesuaikan dengan tingkat penguasaannya,

4. Kemampuan merekam aktivitas siswa selama menggunakan suatu program pembelajaran memberi kesempatan lebih baik untuk pembelajaran secara perorangan dan perkembangan setiap siswa selalu dapat dipantau.

5. Dapat berhubungan dengan, dan mengendalikan, peralatan lain seperti compact disc, video tape, dan lain-lain dengan menggunakan komputer.

Menurut Gerlach dan Ely (1971) yang dikutip dari Azhar Arsyad (2013:162), bahwa multimedia secara umum diartikan sebagai lebih dari satu media yaitu kombinasi antara teks, grafik, animasi, suara, dan video. Penggabungan ini merupakan kesatuan yang secara bersama-sama menampilkan informasi, pesan atau isi pelajaran. Sedangkan menurut Vaughan (2004) dalam buku yang dikutip Binanto (2010:2), multimedia merupakan kombinasi teks, seni, suara, gambar, animasi, dan video yang disampaikan menggunakan komputer secara interaktif.

Menurut Binanto (2010:2), jenis-jenis multimedia yaitu:

1. Multimedia interaktif, dikatakan multimedia interaktif karena pengguna dapat mengontrol kapan dan apa komponen multimedia akan ditampilkan,

2. Multimedia linier, dikatakan multimedia linier karena pengguna hanya bisa menonton dan menikmati hasil produk multimedia yang disajikan. Dari beberapa pengertian multimedia diatas menurut Binanto (2010:2)

3. Grafik, merupakan suatu penyajian visual yang dipakai untuk membandingkan perbedaan jumlah dari data pada saat yang berbeda-beda. Menurut Arsyad (2013:132), grafik menampilkan sajian visual data angka-angka. Grafik juga dapat menggambarkan hubungan dan perbandingan antara unit-unit data. Ada empat macam grafik utama yaitu grafik batang, garis, lingkaran, dan gambar.

4. Video, berasal dari kata latin yang berarti "saya lihat". Menurut Binanto (2010:179), video adalah teknologi pemprosesan sinyal elektronik yang mewakilkan gambar bergerak. Amplikasi umum dari teknologi video adalah televisi.Video juga dapat digunakan dalam amplikasi teknik, 
keilmuwan, produksi, dan keamanan. Saat ini ada dua macam kategori video yaitu video analog dan video digital.

Menurut Arsyad (2013:97) menjelaskan bahwa, interaksi dalam lingkungan pembelajaran berbasis komputer meliputi tiga unsur, yaitu:

1. Urutan-urutan instruksional yang dapat disesuaikan,

2. Jawaban atau respons atau pekerjaan siswa,

3. Umpan balik yang dapat disesuaikan.

Menurut Jhonson (2002:57)

mengemukakan bahwa pembelajaran dan pengajaran kontekstual melibatkan para siswa dalam aktivitas penting yang membantu mereka mengaitkan pelajaran akademis dengan konteks kehidupan nyata yang mereka hadapi. Dengan mengaitkan keduanya, siswa dapat melihat makna dalam tugas sekolah.

Sedangkan menurut Sanjaya (2006:253) mendefinikan CTL sebagai suatu strategi pembelajaran yang menekankan kepada proses keterlibatan siswa secara penuh untuk menemukan materi yang dipelajari dan menghubungkannya dengan situasi kehidupan nyata.

Materi pelajaran dalam konteks CTL bukan berupa hafalan dan kemudian dilupakan, akan tetapi sebagai bekal mereka dalam mengarungi kehidupan nyata. Menurut Sanjaya (2006:254) terdapat lima karakteristik penting dalam proses pembelajaran kontekstual, yaitu:

1. Pembelajaran merupakan proses pengaktifan pengetahuan yang sudah ada (activiting knowledge), artinya apa yang akan dipelajari tidak terlepas dari pengetahuan yang sudah dipelajari, dengan demikian pengetahuan yang akan diperoleh siswa adalah pengetahuan yang utuh yang memiliki keterkaitan satu sama lain.

2. Pembelajaran kontekstual adalah belajar dalam rangka memperoleh dan menambah pengetahuan baru (acquiring knowledge). Pengetahuan baru itu diperoleh dengan cara deduktif, artinya pembelajaran dimulai dengan mempelajari secara keseluruhan, kemudian memperhatikan detailnya.

3. Pemahaman pengetahuan (understanding knowledge), artinya pengetahuan yang diperoleh siswa bukan untuk dihafal tetapi untuk dipahami dan diyakini.

4. Mempraktikkan pengetahuan dan pengalaman tersebut (applying knowledge), artinya pengetahuan dan pengelaman yang diperolehnya harus diaplikasikan dalam kehidupan siswa, sehingga tampak perubahan perilaku siswa dalam kehidupan sehari-hari.

5. Melakukan refleksi (reflecting knowledge) terhadap strategi pengembangan pengetahuan. Hal ini dilakukan sebagai umpan balik untuk proses perbaikan dan penyempurnaan strategi.

CTL sebagai suatu pendekatan pembelajaran memiliki tujuh asas. Asas ini yang melandasi pelaksanaan proses pembelajaran dengan pendekatan CTL. Sering kali asas ini disebut juga komponen-komponen CTL. Sanjaya (2006:262) menjelaskan tujuh komponen tersebut, yaitu (1) kontruktivisme (contructivism), (2) menemukan (inquiry), (3) bertanya (questioning), (4) masyarakat-belajar (learning community), (5) pemodelan (modeling), (6) refleksi (reflection) dan (7) penilaian yang sebenarnya (authentic assessment).

Alasan peneliti menggunakan program Adobe Flash Professional CS6 sebagai software dalam pembuatan media pembelajaran dikarenakan software ini memiliki beberapa kelebihan. Beberapa kelebihan Adobe Flash Professional CS6 menurut Pramono (2006:2) adalah:

1) Hasil akhir file flash memiliki ukuran yang lebih kecil (setelah dipublish),

2) Adobe Flash Professional CS6 mampu mengimpor hampir semua file gambar dan file audio sehingga presentasi dengan flash lebih hidup,

3) Animasi dapat dibentuk dijalankan dan dikontrol,

4) Flash mampu membuat file executable (*.exe) sehingga dijalankan pada pc manapun tanpa harus menginstal terlebih dahulu,

5) Font presentasi tidak akan berubah meskipun pc yang digunakan tidak memiliki font tersebut,

6) Gambar flash merupakan gambar vektor sehingga tidak pecah meskipun dizoom beratus kali,

7) Adobe Flash Professional CS6 mampu dijalankan pada sistem operasi windows maupun macintosh,

8) Hasil akhir dapat disimpan dalam berbagai macam bentuk atau file dengan bermacam format.

\section{METODE}


Penelitian pengembangan media belajar interaktif dalam pembelajaran berbasis CTL pada bidang studi ekonomi ini dilaksanakan di SMA Negeri 20 Medan.

Penelitian ini merupakan penelitian pengembangan yang akan menghasilkan produk berupa media pembelajaran interaktif berdasarkan temuan uji di lapangan. Borg \& Gall (dalam Sugiyono 2013:9) menyatakan bahwa penelitian dan pengembangan (Research and Development/ $R \& D$ ) merupakan metode penelitian yang digunakan untuk mengembangkan dan memvalidasi produkproduk yang digunakan dalam pendidikan dan pembelajaran.

Metode penelitian dan pengembangan menurut Sugiyono (2013:407), adalah metode penelitian yang digunakan untuk menghasilkan produk tertentu dan menguji keefektifan produk tersebut. Untuk dapat menghasilkan media pembelajaran, maka digunakan penelitian yang bersifat analisis kebutuhan dan menguji keefektifan media pembelajaran supaya berfungsi dengan baik di lapangan (sekolah).

Model pengembangan menurut Sugiyono (2013:409), terdiri dari sepuluh langkah, yaitu: (1) potensi dan masalah; (2) pengumpulan data; (3) desain produk; (4) validasi desain; (5) revisi desain; (6) uji coba produk; (7) revisi produk; (8) uji coba pemakaian; (9) revisi produk; (10) produksi massal.

Pada tahap ini dilakukan kajian tujuan umum tentang pembelajaran ekonomi pada materi kebutuhan dan kelangkaan. Tujuan pembelajaran secara umum yaitu untuk menentukan apa yang didapatoleh siswa setelah mengikuti proses pembelajaran. Merumuskan tujuan pembelajaran menurut Dick dan Carey (dalam Hamzah 2004: 141) terdiri dari: (1) tujuan harus menguraikan apa yang akan dapat dikerjakan oleh siswa; (2) menyebutkan tujuan, memberikan kondisi atau keadaan yang menjadi syarat, yang hadir pada waktu siswa berbuat; dan (3) menyebutkan kriteria yang digunakan untuk menilai perbuatan siswa yang dimaksudkan pada tujuan.

Hamzah (2004:141) mengidentifikasi karakteristik siswa dilakukan untuk mengetahui kualitas perorangan yang dijadikan sebagai petunjuk dalam mendiskripsikan strategi pengelolaan pembelajaran yang meliputi aspekaspek berupa bakat, motivasi belajar, gaya belajar kemampuan berpikir, minat dan kemampuan awal. Dalam kajian tentang karakteristik siswa peneliti melakukan analisis terhadap hasil belajar, pengamatan terhadap kegiatan belajar siswa serta melakukan wawancara dengan guru dan siswa pada bidang studi ekonomi.

Menurut Sugiyono (2013:414), validasi produk dapat dilakukan dengan cara menghadirkan beberapa pakar atau tenaga ahli yang sudah berpengalaman untuk menilai produk baru yang dirancang tersebut. Setiap pakar diminta untuk menilai desain tersebut, sehingga selanjutnya dapat diketahui kelemahan dan kekuatannya. Validasi desain dapat dilakukan dalam forum diskusi. Sebelum diskusi peneliti mempresentasikan proses penelitian sampai ditemukan desain tersebut, berikut keunggulannya. Tahap validasi, meliputi: (1) validasi ahli materi; (2) validasi ahli media; dan (3) guru bidang studi menilai keduanya.

Sadiman (2005:183) menjelaskan tentang jumlah subjek uji coba yang terdiri dari uji coba satu-satu adalah 2 siswa, uji coba kelompok kecil sebanyak 9-20 siswa, dan uji coba lapangan 30 siswa. Hal senada juga disampaikan oleh Dick and Carey (dalam Pribadi 2009:107), mengemukakan bahwa evaluasi formatif dapat dilakukan dengan tiga tahap yaitu evaluasi perseorangan (uji coba satu-satu) pada 1-3 siswa, evaluasi kelompok kecil dengan mengujicobakan produk pada kelompok kecil yang terdiri dari 10-15 siswa, dan uji coba lapangan dengan melibatkan subjek uji coba pada skala yang lebih luas.

Uji coba kelompok kecil dimaksudkan untuk mengidentifikasi permasalahan awal ketika media digunakan. Melalui uji kelompok kecil diharapkan tidak ada masalah yang mendasar ketika media pembelajaran interaktif berbasis CTL digunakan. Pada uji coba ini yaitu dengan mengumpulkan 10-17 siswa calon pengguna produk dalam hal ini adalah siswa kelas XI SMA Negeri 20 Medan yang dianggap memiliki karakteristik yang sama dengan siswa yang akan menjadi target sasaran. Pengambilan untuk uji coba kelompok kecil dilakukan dengan teknik simple random sampling. Sugiyono (2013:120) mengemukakan bahwa simple random sampling merupakan pengambilan anggota sampel dari populasi yang dilakukan secara acak tanpa memperhatikan strata yang ada dalam populasi itu. Siswa yang terpilih dalam uji coba kelompok kecil diminta memberikan komentar atau masukan tentang program tersebut dengan mengisi angket yang 
dibagikan. Berdasarkan masukan dari uji kelompok kecil ini dijadikan sebagai bahan untuk merevisi produk.

Menurut Sugiyono (2013:308), pengumpulan data dapat dilakukan dalam berbagai setting, berbagai sumber, dan berbagai cara. Bila dilihat dari segi cara atau teknik pengumpulan data, maka teknik pengumpulan data dapat dilakukan dengan : observasi (pengamatan), interview (wawancara), kuesioner (angket), dokumentasi dan gabungan keempatnya. Namun pada pengumpulan data penelitian ini menggunakan interview (wawancara) dan kuesioner (angket).

Menurut Sugiyono (2013:329)

mengatakan bahwa kuesioner (angket) merupakan teknik pengumpulan data yang dilakukan dengan cara memberi seperangkat pertanyaan atau pernyataan tertulis kepada responden untuk dijawab. Kuesioner dapat berupa pertanyaan-pernyataan tertutup atau terbuka, dapat diberikan kepada responden secara langsung atau dikirim melalui pos atau internet.

Menurut Sugiyono (2013:305), bahwa Kisi-Kisi Instrumen digunakan untuk mengetahui tingkat keberhasilan dari suatu penelitian. Alat ukur dalam penelitian dinamakan Kisi-Kisi Instrumen penelitian. KisiKisi Instrumen penelitian adalah suatu alat yang digunakan untuk mengukur fenomena alam maupun sosial yang diamati.

Sugiyono (2013:105) menjelaskan bahwa instrumen digunakan untuk mengetahui tingkat keberhasilan dari suatu penelitian. Alat ukur dalam penelitian dinamakan instrumen penelitian. Instrumen penelitian adalah suatu alat yang digunakan untuk mengukur fenomena alam maupun sosial yang diamati.

Reliabilitas dianalisis dengan rumus alpha cronbach. Rumus ini secara spesifik digunakan untuk model instrumen berupa angket penelitian yang memiliki karakteristik data berupa dana berslaka likert. Rumus reliabilitas alpha yang digunakan adalah:

Keterangan :

$$
r 11=\left[\frac{k}{k-1}\right]\left[1-\frac{\Sigma \sigma n^{2}}{\sigma t^{2}}\right]
$$

r11 : Reliabilitas instrumen

$\mathrm{k}$ : Banyaknya butir pertanyaan atau banyaknya item

$\Sigma \sigma_{\mathrm{n}}^{2}$ : Jumlah varians butir

$\sigma_{\mathrm{t}}^{2} \quad$ : Varians total

(Sudjana, 2005:109)

Dengan varians butir :

$$
\sigma_{n}^{2}=\frac{\Sigma X^{2}-\frac{(\Sigma X)^{2}}{n}}{n}
$$

Dan varians total: $\quad \sigma_{t}^{2}=\frac{\Sigma Y^{2}-\frac{(\Sigma Y)^{2}}{n}}{n}$

Tabel 1. Kriteria Reliabilitas Angket

\begin{tabular}{cc}
\hline Interval reliabilitas & Kriteria \\
\hline $0,000<\mathrm{r} \leq 0,200$ & Sangat rendah \\
$0,200<\mathrm{r} \leq 0,400$ & Rendah \\
$0,400<\mathrm{r} \leq 0,600$ & Cukup \\
$0,600<\mathrm{r} \leq 0,800$ & Tinggi \\
$0,800<\mathrm{r} \leq 1,000$ & Sangat tinggi \\
\hline
\end{tabular}

Angket tanggapan pengguna terhadap media digunakan untuk mengukur tingkat kelayakan reliabilitas media. Angket berisi pertanyaan-pertanyaan yang mengacu pada efektifitas penggunaan media. Angket ini digunakan saat dilakukan uji coba skala kecil dan uji coba skala besar.

\section{Analisis Kelayakan Atau Analisis Validasi (Media Pembelajaran Interaktif)}

Tingkat kelayakan dihitung dengan persamaan berikut :

$$
\%=\frac{n}{N} x 100 \%
$$

Keterangan :

$\%=$ persentase skor kelayakan

$\mathrm{n} \quad=$ jumlah skor yang diperoleh

$\mathrm{N} \quad=$ jumlah skor maksimal

Hasil penilaian dianalisis dengan kriteria yang disajikan seperti dibawah ini:

Tabel 2. Kategori Skala Likert

\begin{tabular}{cc}
\hline Skor Nilai & Keterangan \\
\hline 5 & Sangat Layak \\
4 & Layak \\
3 & Cukup Layak \\
2 & Tidak Layak \\
1 & Sangat Tidak Layak \\
\hline
\end{tabular}

Keseluruhan penilaian validator dan guru SMA dilihat dari empat aspek yaitu isi materi, desain pembelajaran, tampilan dan penyajian serta pemrograman diperoleh hasil dengan kategori lebih dari "Layak". Oleh karena itu, media interaktif yang dikembangkan dikatakan "Layak" digunakan dalam pembelajaran dan menunjang pembelajaran kontekstual (CTL) sesuai dengan kategori yang sudah ditentukan. Persentase rerata skor penilaian kelayakan tiap aspek dan pendapat ahli serta guru dapat dilihat pada Tabel 3 berikut: 
JURNAL TEKNOLOGI INFORMASI \& KOMUNIKASI dalam PENDIDIKAN, Vol. 5 No. 1 Juni 2018, p-ISSN; 2355-4983, e-ISSN: 2407-7488

Tabel 3. Persentase Rerata Skor Penilaian Kelayakan Tiap Aspek dan Pendapat Ahli serta Guru SMA

\begin{tabular}{|c|c|c|c|c|c|c|}
\hline \multirow[b]{2}{*}{ No } & \multirow[b]{2}{*}{ Penilaian } & \multirow[b]{2}{*}{$\begin{array}{c}\text { Skor } \\
\text { Maksimal }\end{array}$} & \multicolumn{4}{|c|}{ Validator } \\
\hline & & & $\begin{array}{c}\text { Ahli } \\
\text { Materi }\end{array}$ & $\begin{array}{l}\text { Ahli } \\
\text { Media }\end{array}$ & $\begin{array}{c}\text { Ahli } \\
\text { Desain }\end{array}$ & $\begin{array}{l}\text { Guru } \\
\text { SMA }\end{array}$ \\
\hline 1 & Aspek Isi Materi & 90,00 & $\begin{array}{c}67,50 \\
(75,00 \%)\end{array}$ & - & - & $\begin{array}{c}68,50 \\
(76,11 \%) \\
\end{array}$ \\
\hline \multirow{3}{*}{2} & \multirow{3}{*}{ Aspek Pembelajaran } & $\begin{array}{l}\text { Ahli Desain: } \\
\text { 30,00 }\end{array}$ & - & - & $\begin{array}{c}24,00 \\
(80,0 \%)\end{array}$ & - \\
\hline & & $\begin{array}{l}\text { Ahli Materi: } \\
\quad 60,00\end{array}$ & $\begin{array}{c}44,50 \\
(74,17 \%)\end{array}$ & - & - & - \\
\hline & & $\begin{array}{l}\text { Guru SMA: } \\
\quad 60,00\end{array}$ & - & - & - & $\begin{array}{c}47,00 \\
(78,33 \%)\end{array}$ \\
\hline \multirow{2}{*}{3} & \multirow{2}{*}{$\begin{array}{l}\text { Aspek Tampilan dan } \\
\text { Penyajian }\end{array}$} & $\begin{array}{c}\text { Ahli Media: } \\
\quad 115,00\end{array}$ & - & $\begin{array}{c}98,50 \\
(85,7 \%)\end{array}$ & - & \\
\hline & & $\begin{array}{l}\text { Guru SMA: } \\
\quad 85,00\end{array}$ & - & - & - & $\begin{array}{c}65,00 \\
(76,47 \%)\end{array}$ \\
\hline \multirow{2}{*}{4} & \multirow{2}{*}{ Aspek Pemrograman } & $\begin{array}{l}\text { Ahli Media: } \\
\quad 60,00\end{array}$ & - & $\begin{array}{c}52,00 \\
(86,7 \%)\end{array}$ & - & - \\
\hline & & $\begin{array}{c}\text { Guru SMA: } \\
65,00\end{array}$ & - & - & - & $\begin{array}{c}50,00 \\
(76,92 \%)\end{array}$ \\
\hline 5 & $\begin{array}{l}\text { Pendapat kesesuaian } \\
\text { media menunjang CTL }\end{array}$ & 60,00 & $\begin{array}{c}43,50 \\
(72,50 \%)\end{array}$ & $\begin{array}{c}53,50 \\
(89,2 \%)\end{array}$ & $\begin{array}{c}48,00 \\
(80,0 \%)\end{array}$ & $\begin{array}{c}44,50 \\
(74,17 \%)\end{array}$ \\
\hline
\end{tabular}

Persentase rerata skor di atas menunjukkan perbandingan hasil penelitian masing-masing aspek dan pendapat validator. Pada tahap validasi, aspek yang memperolah penilaian tertinggi adalah aspek pendapat kesesuaian media menunjang CTL berdasarkan penilaian ahli media yaitu sebesar $89,2 \%$ kemudian pendapat media yang menunjang CTL perolehan nilai paling tinggi sebesar $89,2 \%$ oleh ahli media. Persentase penilaian terendah terdapat pada aspek kesesuaian media menunjang pembelajaran sebesar $72,50 \%$ oleh ahli materi. Hal ini dapat dijadikan sebagai dasar untuk menafsirkan bahwa aspek kesesuaian media menunjang pembelajaran perlu ditingkatkan kualitasnya diantara aspek yang lainnya agar lebih baik.

Berdasarkan hasil analisis dari penilaian keempat aspek pada tahap uji coba di atas, diketahui bahwa kelayakan keseluruhan aspek isi materi, pembelajaran, tampilan dan penyajian serta aspek pemrograman dari uji coba kelompok kecil maupun uji coba lapangan termasuk pada kategori "Sangat Layak". Namun demikian, jika dianalisis lebih dalam dari keempat aspek pada tahap uji coba aspek isi materi memperoleh penilaian paling tinggi. Pernyataan ini dapat dilihat pada tabel 4 . berikut:

Tabel 4. Presentase Rerata Skor Hasil Penilaian Tahap Uji Coba pada Tiap Aspek

\begin{tabular}{|c|c|c|c|c|c|}
\hline \multirow{2}{*}{ No } & \multirow{2}{*}{ Penilaian } & \multirow{2}{*}{$\begin{array}{l}\text { Skor } \\
\text { Maks. }\end{array}$} & \multicolumn{3}{|c|}{ Responden } \\
\hline & & & Uji Kel. Kecil & Uji Kel. Besar & Rata-rata \\
\hline \multirow{2}{*}{1} & \multirow{2}{*}{ Aspek isi materi } & \multirow{2}{*}{65,00} & $56,81(87,4 \%)$ & $56,90(87,5 \%)$ & $56,86(87,5 \%)$ \\
\hline & & & Sangat Layak & Sangat Layak & Sangat Layak \\
\hline \multirow{2}{*}{2} & \multirow{2}{*}{$\begin{array}{l}\text { Aspek } \\
\text { pembelajaran }\end{array}$} & \multirow{2}{*}{25,00} & $21,25(85,0 \%)$ & $21,50(86,0 \%)$ & $21,38(85,5 \%)$ \\
\hline & & & Sangat Layak & Sangat Layak & Sangat Layak \\
\hline \multirow{2}{*}{3} & \multirow{2}{*}{$\begin{array}{l}\text { Aspek tampilan } \\
\text { dan penyajian }\end{array}$} & \multirow{2}{*}{85,00} & $71,38(83,98)$ & $72,50(85,3 \%)$ & $71,94(84,6 \%)$ \\
\hline & & & Sangat Layak & Sangat Layak & Sangat Layak \\
\hline \multirow{2}{*}{4} & \multirow{2}{*}{$\begin{array}{l}\text { Aspek } \\
\text { pemrograman }\end{array}$} & \multirow{2}{*}{60,00} & $50,38(83,97)$ & $51.03(85,1 \%)$ & $50,71(84,5 \%)$ \\
\hline & & & Sangat Layak & Sangat Layak & Sangat Layak \\
\hline
\end{tabular}

Berdasarkan tabel pada analisis uji coba Skala Kecil diperoleh :
$\Sigma \sigma_{\mathrm{n}}^{2}=0,23+0,28+\ldots+0,31=14,45$

$\sigma_{\mathrm{t}}^{2}=\underline{13832-((3196) / 16)}=85,2$ 


$$
\begin{aligned}
\mathrm{r} 11= & (16 / 16-1)(1-(14,45 / 85,2))=1,07(1- \\
& 0,17) \\
= & 1,07 \times 0,83 \\
= & 0,890
\end{aligned}
$$

Kriteria reliabilitas angket ditunjukkan pada Tabel Klasifikasi Reliabilitas berikut:

Tabel 5. Klasifikasi Reliabilitas

\begin{tabular}{cc}
\hline Interval & Kriteria \\
\hline $0,800-1,000$ & Sangat Layak \\
$0,600-0,799$ & Layak \\
$0,400-0,599$ & Cukup Layak \\
$0,200-0,399$ & Tidak Layak \\
$0,000-0,199$ & Sangat Tidak Layak \\
\hline
\end{tabular}

Hasil perhitungan diperoleh reliabiltias $\left(\mathrm{r}_{11}\right)=$ 0,890

Instrumen reliabel dengan kriteria "Sangat

Layak"

Perhitungan Reliabilitas Angket Media Terhadap Siswa Pada Uji Coba Skala Besar

Berdasarkan tabel pada analisis uji coba Skala Kecil diperoleh :

$$
\begin{aligned}
& \Sigma \sigma_{\mathrm{n}}^{2}=0,21+0,24+\ldots+0,25=12,20 \\
& \sigma_{\mathrm{t}}{ }^{2}=\frac{35219-((8077) / 40)}{40}=87,5 \\
& \mathrm{r} 11=(40 / 40-1)(1-(12,20 / 87,5))=1,03(1- \\
& \begin{aligned}
0,14) \\
\quad=1,03 \times 0,84 \\
\quad=0,870
\end{aligned}
\end{aligned}
$$

Kriteria reliabilitas angket ditunjukkan pada Tabel Klasifikasi Reliabilitas berikut:

Tabel 4.19. Klasifikasi Reliabilitas

\begin{tabular}{cc}
\hline Interval reliabilitas & Kriteria \\
\hline $0,800-1,000$ & Sangat Layak \\
$0,600-0,799$ & Layak \\
$0,400-0,599$ & Cukup Layak \\
$0,200-0,399$ & Tidak Layak \\
$0,000-0,199$ & Sangat Tidak \\
\hline
\end{tabular}

Hasil perhitungan diperoleh reliabiltias $\left(\mathrm{r}_{11}\right)=$ 0,870

Instrumen reliabel dengan kriteria "Sangat Layak"

\section{PENUTUP}

Pertama, pengembangan media belajar interaktif telah dikembangkan sesuai dengan prosedur pengembangan dengan langkah 1) potensi dan masalah; 2) pengumpulan data (bahan); 3) desain produk (desain software atau program dan assembly,) pada tahap desain program meliputi desain alur kerja dan desain struktural; 4) validasi desain; 5) revisi desain; 6) uji coba produk; 7) revisi produk; 8) produksi media.

Kedua, pengembangan media belajar interaktif ditinjau dari aspek isi materi, aspek pembelajaran, aspek penyajian dan tampilan, serta aspek pemrograman "Layak" digunakan dalam pembelajaran ekonomi di SMA.

Pendapat ahli materi mengenai media belajar yang menunjang pembelajaran kontekstual (CTL) termasuk dalam kategori "Layak", demikian juga pendapat ahli materi, ahli media dan guru ekonomi di SMA Negeri 20 Medan termasuk dalam kategori "Layak". Berdasarkan pendapat dari validator, maka disimpulkan bahwa media belajar interaktif yang dikembangkan telah menunjang pelaksanaan pembelajaran berbasis kontekstual (CTL).

\section{DAFTAR PUSTAKA}

Abrianto, D dan Sitompul, H. 2014. Penggunaan Media Pembelajaran Berbasis Komputer dan Sikap Inovatif Terhadap Hasil Belajar Teknologi Informasi dan Komunikasi. Jurnal Program Studi Teknologi Pendidikan Pascasarjana Unimed. Ikatan Pengembang Teknologi Pendidikan Indonesia. Volume. 1, No. 2, Desember 2014

Arsyad, A. 2013. Media Pembelajaran. Jakarta: PT. RajaGrafindo Persada

Binanto, I. 2010. Multimedia Digital-Dasar Teori dan Pengembangannya. Yogyakarta: CV ANDI OFFSET

Daryanto. 2010. Media Pembelajaran. Yogyakarta: Gava Media Depdiknas. 2008. Panduan Pengembangan Bahan Ajar.

Dick, W., Carey, L. And Carey, J. O. (2009). The Systematic Design of Instruction (7th Ed.). New Jersey: Pearson.

Gagne, R.M., \& Briggs, L.J. (1979). Principles of instructional design (edisi ke-2). New York: Holt, Rinehart \& Winston.

Hamzah, B., dkk. 2004. Model Pembelajaran. Gorontalo: BMT Nurul Jannah.

Harningsih, A.S.S dan Napitupulu, E. 2014. Penggunaan Multimedia Pembelajaran Interaktif dan Kreativitas Terhadap Hasil Belajar Teknologi Informasi dan Komunikasi (TIK). Jurnal Program Studi Teknologi Pendidikan Pascasarjana Unimed. Ikatan Pengembang Teknologi 
Pendidikan Indonesia. Volume. 1, No. 1, Juni 2014.

Hendra dan Siagian, S. 2014 Penggunaan Media Pembelajaran Interaktif dan Komunikasi Interpersonal Terhadap Hasil Belajar Kimia. Jurnal. Program Studi Teknologi Pendidikan Pascasarjana Unimed. Ikatan Pengembang Teknologi Pendidikan Indonesia. Volume. 1, No. 1, Juni 2014.

Husairi, A. dan Sibuea, A.M. 2014 Penggunaan Media Pembelajaran dan Kecerdasan Ganda Terhadap Hasil Belajar IPS. Jurnal Program Studi Teknologi Pendidikan Pascasarjana Unimed. Ikatan Pengembang Teknologi Pendidikan Indonesia. Volume. 1, No. 1, Juni 2014.

Jhonson, E.B. 2002. Contextual Teaching And Learning. What It Is And Why It's Here To Stay. Teaching - United States. Learning Psychology Of.

Nazarudin. 2007. Managemen Pembelajaran. Yogyakarta : Teras

Pangaribuan, F.A dan Saragih, A.H. 2014. Pengembangan Multimedia Pembelajaran Interaktif Mata Kuliah Seni Lukis 1 Jurusan Seni Rupa. Jurnal Program Studi Teknologi Pendidikan Pascasarjana Unimed. Ikatan Pengembang Teknologi Pendidikan Indonesia. Volume. 1, No. 1, Juni 2014.

Pramono, A. 2006. Presentasi Multimedia dengan Macromedia Flash. Yogyakarta: Andi Offset

Pribadi, B. 2009. Model Desain Sistem Pembelajaran. Jakarta: PT Dian Rakyat
Riyanto, Y. 2009. Paradigma Baru Pembelajaran: Sebagai Referensi bagi Guru Pendidik dalam Implementasi Pembelajaran yang Efektif dan Berkualitas. Jakarta: Kencana Prenada Media Group

Roymond, H \& Simamora. 2009. Buku Ajar Pendidikan Dalam Keperawatan. Jakarta: EGC

Sadiman, A.S. 2014. Media Pendidikan Pengertian, Pengembangan, dan Pemanfaatannya. Jakarta: PT RajaGrafindo Persada

Sanjaya, W. 2006. Strategi Pembelajaran Berorientasi Standar Proses Pendidikan. Jakarta: Kencana Prenada Media Group

Schunk, D.H. 2012. Learning Theories an Educational Perspective. Yogyakarta: Pustaka Pelajar

Sihotang, B dan Mursid, R. 2014. Penggunaan Multimedia Pembelajaran dan Kecerdasan Interpersonal Siswa Terhadap Hasil Belajar Tune Up Motor Bensin. Jurnal Program Studi Teknologi Pendidikan Pascasarjana Unimed. Ikatan Pengembang Teknologi Pendidikan Indonesia. Volume. 1, No. 1, Juni 2014.

Sudarman, A. 1999. Teori Ekonomi Mikro. Yogyakarta: BPFE

Sudjana, N \& Rivai, A. 2002. Media Pengajaran. Bandung: CV Sinar Baru

Sugiyono. 2013. Metode Penelitian Pendidikan (Pendekatan Kuantitatif, Kualitatif dan R\&D). Bandung: ALFABETA 